IdeAs

Idées d'Amériques

$14 \mid 2019$

Populismes dans les Amériques

\title{
Populist Narratives from Below: Occupy Wall Street and the Tea Party
}

Récits populistes d'en bas: Occupy Wall Street et le Tea Party

Narrativas populistas desde abajo: Occupy Wall Street y el Tea Party

Rachel Meade

(2) OpenEdition

Journals

Electronic version

URL: http://journals.openedition.org/ideas/5833

DOI: 10.4000/ideas.5833

ISSN: 1950-5701

Publisher

Institut des Amériques

Electronic reference

Rachel Meade, « Populist Narratives from Below: Occupy Wall Street and the Tea Party », IdeAs

[Online], 14 | 2019, Online since 01 October 2019, connection on 08 November 2019. URL : http:// journals.openedition.org/ideas/5833; DOI : 10.4000/ideas.5833

This text was automatically generated on 8 November 2019

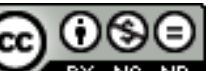

IdeAs - Idées d'Amériques est mis à disposition selon les termes de la licence Creative Commons Attribution - Pas d'Utilisation Commerciale - Pas de Modification 4.0 International. 


\title{
Populist Narratives from Below: Occupy Wall Street and the Tea Party
}

Récits populistes d'en bas: Occupy Wall Street et le Tea Party Narrativas populistas desde abajo: Occupy Wall Street y el Tea Party

\author{
Rachel Meade
}

\section{Populism as Trumpism?}

1 While examples of left-wing and grassroots movements that use populist discourse abound, we tend to associate populism particularly with the right, political leaders, and authoritarianism. When Jair Bolsonaro won the Brazilian presidency in 2018, international media quickly classified him as the latest iteration of the worldwide populist phenomenon. "Brazil's firebrand leader dubbed Trump of the Tropics" blared the BBC (2018). A Washington Post story headlined "Making Brazil Great Again," described him as someone "elected as a populist promising to shake up politics as usual." So who exactly is this populist firebrand? Bolsonaro certainly shares some Trump-like appeal, running on a law and order and nationalistic platform and attracting the support of conservative evangelicals with his defense of 'traditional' families. Yet in his repeated praise of the military dictatorship which killed hundreds of citizens and tortured thousands-which he argues erred only in not killing enough leftists-he appears more fascist than populist. In fact, Bolsonaro's right-wing authoritarianism represents just one in a variety of populist responses to global political and economic structures that are increasingly viewed as unrepresentative and illegitimate. Populism has also sprung up on the left, in Spain's Podemos party and Latin America's "pink tide" governments of the 2000s, and at the grassroots, with the twin US responses to the 2008 economic crisis-the Tea Party and Occupy Wall Street.

Given this diverse array of populist responses, why have the Trumps and Bolsonaros of the world become shorthand for populism? Furthermore, what do regimes like Trump's 
and Bolsonaro's, which are hostile to immigrants and seek to centralize power in the executive, have in common with Occupy Wall Street, a horizontal, cross-national movement calling for reform of capitalist economic structures? And why are such dissimilar varieties of populism emerging at this particular moment?

3 I argue that academics' top-down focus on populist discourse and their normative attitudes about the role of the people in democracy have contributed to conceptions of populism that emphasize leader-centric and right-wing varieties. This emphasis obscures the fact that current and historical left-wing and grassroots movements also display populist discourse; it also obscures the role of democratic practices in constructing populist movements. Furthermore, ideological definitions elide populism's flexible nature as a search for alternatives to democratic institutions that are perceived as corrupt and unrepresentative.

4 In this paper, I draw on ethnographic observations and interviews conducted in 2016 and 2017 with members of an Occupy Wall Street ${ }^{1}$ and a Tea Party group in Traverse City, Michigan, to illustrate the characteristics of left-wing populist movements and show how the latter both overlap and diverge from right-wing populism. Such groups are important for understanding populist identity since populist discourse contends that mainstream sources of information such as the media can't be trusted, thus leading supporters to turn to their trusted communities for political information. Furthermore, since the categories that comprise populist discourse-the "people" and the "elite"-are imagined in different ways by individuals in different social and regional contexts, local studies of political groups are crucial for understanding why people support populism. Typical methods for studying populism-analysis of elite populist discourse or individual-level surveys-miss this communal aspect of populism.

5 Overall, I found that for members of both groups, populist narratives and grassroots participation helped them make sense of and respond to political and societal changes relating to the globalization and financialization of the economy. Yet members of the Occupy group exclusively blamed economic and political elites, whereas Tea Party members additionally blamed citizens they saw as threatening to the nation's values or as unfairly profiting off the backs of hard-working Americans. As a result, Occupy's conception of the populist "people" is more inclusionary than the Tea Party's, thus positioning it to create populist institutional change that presents a truly democratic challenge to the status quo. Before discussing these ethnographic findings, I review existing definitions and explanations for populist politics.

\section{Towards a Bottom-up Approach to Populism}

6 Scholars of comparative populism have recently coincided in agreeing that populism is a "thin-centered ideology" that pits a pure, homogenous national people against a corrupt elite (Mudde C., 2007). Scholars use this definition to measure and compare the populist discourse used by politicians, and to identify the attitudes and characteristics of populist voters (Hawkins K., 2009; Akkerman A., et. al. 2014). While revealing consistent patterns in populist discourse and support across time and place, these studies emphasize a top-down conception of populism as consisting of support for political language which employs populist language.

7 Meanwhile, in the years since Donald Trump's election, media and academics have increasingly presented populism as synonymous with exclusionary right-wing and 
authoritarian regimes and as a threat to democracy. These accounts reveal fears that scholars hold about popular sovereignty and rule by the people in general. Nadia Urbinati (2017) and Jan-Werner Muller (2016) each argue that populism's claim to represent a homogenous national people makes it inherently incompatible with democracy and pluralism. Urbinati focuses on populist discourse that is articulated by a populist leader in power, arguing that in this case it leads to majoritarian rule hostile to the institutions of liberal democracy (2017). Muller makes a similar point, noting that since populist leaders claim exclusive authority to represent the people, their administrations are inherently hostile to the opposition. Since he sees populism as antipluralist, Muller excludes many cases of left-wing populism from his definitionincluding movements like Occupy Wall Street or the politics of Bernie Sanders.

8 Similarly, another set of scholars fear that the people's ignorance and psychological maladies make them susceptible to elite manipulation. These scholars also tend to focus particularly on cases of right-wing populism. Hofstadter diagnoses 1960s rightwing anti-communism as "a paranoid style" of thinking, while a recent study of Trump and Brexit support blames individually-held "authoritarian values" (Hofstadter R., 1964; Norris P., and Inglehart R., 2019). Meanwhile, Frank blames Republican elites for manipulating poor whites into voting against their interests, while Skocpol suggests that appeals from right-wing think tanks and Fox News resulted in a cooptation of grassroots populist sentiment in the Tea Party (Frank T., 2004; Skocpol V., 2012; Skocpol V. and Hertel-Fernandez A., 2017). Since these explanations point to some inherent limitations in the democratic capacity of citizens-either due to psychological tendencies or propensity for elite manipulation-they also imply that populism poses a danger for democracy.

9 Alternatively, if we recognize what Honig calls the "paradox of democracy"-the always unfulfilled promise that the whole of the democratic "people" would rule themselves-, populism takes on a very different relationship to democracy (2009). This tension is particularly notable in the US, where while the Constitution opens with "We, the People," our federalist system aims to protect against the dangers of direct democracy. As Honig notes, "the people, the so-called center of democratic theory and practice, are always inhabited by the multitude, their unruly, ungovernable other" (2009: 3). One way to understand this tension is to view the political participation and passionate politics of populism as a periodic and necessary counter to institutions that have become overly bureaucratic or unresponsive (Canovan M., 2002). Similarly, Morone argues that throughout US history, the "people" have periodically sought to rejuvenate corrupt government institutions with a communal vision of democracy, paradoxically resulting in increases in the size and scope of national bureaucracy (1998).

In order to view populism as a participatory alternative to unrepresentative institutions we must broaden out from the predominant ideational approach to populism to encompass how movements use discourse and democratic practices to challenge institutions and elites. Laclau's discursive approach to populism comes closest to providing a guide to how grassroots movements might build toward democratic alternatives (2007). He suggests that populism starts not with a leader's discourse, but rather with a set of unfulfilled demands that creates an antagonistic division between the people and their political institutions. The collective "people" are then instantiated either by shared identification with a leader or by a symbolic demand. However, in both his own work and his co-author Mouffe's recent study of left 
populism, only the former possibility is fully examined (2018). As Riofrancos argues, Mouffe's examples for left populism highlight leaders like Corbyn and Sanders. Yet the dramatic institutional change that populist movements seek is only likely to be produced if movements engage in "rebellious grassroots activity" to hold them accountable to their promises (2019:2).

11 Laura Grattan's theoretical study of grassroots populist movements through US history offers a useful counter to the prevailing leader-focused populist studies. She examines not only discourse, but also what she calls "everyday populism," the set of practices by which citizens enact democratic power (2016). She focuses particularly on left-wing populist movements that deepen democracy and challenge status quo institutions, such as the original Populist Party and Occupy Wall Street. On the other hand, she argues that the Tea Party's democratic potential was limited both by its narrow and largely white conception of the people as well as by its mutually beneficial collaboration with right-wing media, thus leading to an individualistic approach to politics that ultimately reinforced the status quo.

Similarly, historian Michael Kazin distinguishes between the democratic capacities of left versus right populism (1995). Unlike many scholars who are suspicious of US populism in particular for its propensity, at least since the 1960s, to align with the right-wing politics of racial backlash and conspiracy, Kazin nevertheless argues that the democratic projects of liberals have only advanced when they used a "hopeful, expansive, even romantic" language of populism (6). In contrast to Mudde's approach to populism as a set ideology, he argues that populism is rather a "flexible mode of persuasion" that "is too elastic and promiscuous" to constitute a clear-cut identity (Kazin M., 1995: 3).

Kazin's understanding of populism as ideologically flexible also aligns with Taggart's contribution to the populist literature-the idea that populist movements contain an implicit or explicit "heartland" that is conjured up in different ways by its participants (Taggart P., 2000). For Taggart, the "heartland" constitutes an idealized version of the past from which populist supporters draw their sense of the characteristics and values that define the movement and its people. While this feature of populism can be seen most clearly in right-wing versions of populism in Western Europe and the US, as in Trump's catchphrase "Make America Great Again," its backward-looking nostalgia is also compatible with left-wing varieties of populism that are centered in opposition to the unequal impacts of globalization on communities.

In the ethnographic analysis that follows, I employ a bottom-up approach to populism to show how the left grassroots populism of Occupy Wall Street both overlaps with and challenges better understood right-wing and leader-centric varieties. Unlike the focus on the discourse and actions of populist leaders, bottom-up conceptions of populism are attentive to the ways citizens participate in enacting democratic power through new forms of mobilization and organization that challenge existing structures. These practices often precede and accompany populist political administrations.

\section{Populist Mobilization in Traverse City}

15 Traverse City is a productive site for studying both left and right populism. The city hosts active Tea Party and Occupy Wall Street groups, both of which have been meeting weekly since their respective movements' formation in 2009 and 2010. Additionally, 
while Clinton won democratic stronghold Traverse City, anti-establishment presidential candidates Donald Trump and Bernie Sanders each had strong support in the region (Bloch M., et. al. 2018). Following the election, multiple chapters of the leftwing activist group Indivisible sprang up. ${ }^{2}$ Finally, Traverse City was also divided in 2016 over a local populist issue-Prop 3, a successful ballot measure to put tax-funded corporate development projects in the downtown up for a vote of the people.

16 I build on a dataset of interviews and observations gathered before and after the 2016 presidential election. This research included semi-structured interviews with key participants, as well as group observations and interviews with populist groups. In the analysis that follows, I draw the majority of quotations and examples from members of the Occupy Wall Street group, which I compare to a local Tea Party group. However, my findings are based on comparison with a broader research sample including Trump, Sanders, and Clinton supporters, anti-Trump Republicans, and supporters of Prop 3. ${ }^{3}$ Members of both groups meet often enough, both in weekly meetings and in other political activities, that they share and receive much of their political information from one another.

Occupy Traverse City has gathered for weekly protests in downtown Traverse City, Michigan, since the beginning of the national movement in 2011. Today the group consists of a core of 10-15 retirees that gather every Saturday, rain, shine, or snow, for two hours of protest downtown, followed by coffee, lunch, and chitchat at a nearby cafe. In general, members tend to be registered Democrats, though some identify as Independents, Socialists, or as members of the Green Party. Many are involved in local and national political advocacy organizations relating to the environment, anti-war, and indigenous rights issues. All strongly supported and some campaigned for Bernie Sanders in the primary, and those that are active in the local Democratic Party call for greater transparency and democratic accountability. It should be noted that the group's demographics-predominantly elderly and white-may diverge from the Occupy movement and left populism more generally.

The local Tea Party group formed after seeing Fox News Glenn Beck's call for American patriots to organize into local political groups in March 2009. The group, which identifies with Beck's 9/12 movement, consists of 15-25 middle aged to elderly "constitutional conservatives" who meet weekly for political discussions and presentations from state and local politicians and think-tanks. ${ }^{4}$ Like the Occupy members, they are engaged outside the group, especially in local politics, serving on county and city boards, and in the Republican Party. While not all members initially supported Donald Trump, they became strong supporters once he won the primary.

19 It should be noted that these groups represent just one possible version of populism, and are not perfectly representative of the broader Occupy and Tea Party movements. Nevertheless, my sustained ethnographic focus on these tight-knit populist groups helps illuminate general patterns of populist socialization, discourse, and identityformation.

\section{Narrative of Decline}

The clearest similarity between members of Occupy and the Tea Party in Traverse City is their shared narrative of national decline. They look back nostalgically to their youth as a model for community, shared values, and moderation, as compared to today's 
polarized era. Supporters of Bernie Sanders and members of the Occupy group cite the increasing power of corporations and special interests and the rising cost of housing, college education, and other staples of life. On the other hand, members of the Tea Party and supporters of Donald Trump are more likely to point towards cultural changes such as a loss of moral values and pride in country, especially among young people. Yet both Occupy and Tea Party members also mention the opposite explanation, suggesting that many link community and cultural losses with economic ones. Finally, in contrast to the recollections of right-wing populists, left populists are less likely to wholly idealize the period, acknowledging that minority populations such as African Americans, women, and the LGBTQ community have made important progress in the intervening years.

Occupy members say the relative economic opportunity and job security of the postwar era has slowly disappeared. Paul recalled how good jobs and affordable education used to be attainable, while nevertheless acknowledging that "I don't think America's ever been great." He described working summer jobs and over Christmas break to pay his way through school and graduating with just $\$ 1200$ in debt. Others say the social safety net supported them through difficult times, as in the case of James, whose father was killed in a car accident just as he started college. However, he said, since "the Great Society was in full swing, the government helped me get a Bachelor's and Master's." Tea Party members have similar reflections. Brenda, a 62-year-old Trump supporter said, “In 1973, guys that didn't want to go to college would go to... Great Lakes Steel and make 60 grand plus full benefits. Back then you could work at one place until you retired, because we were making stuff."

The comparative economic security of the era was most apparent when people compared their early educational and school experiences with those of their children or friends today. Occupy member Charlie, a Green Party voter who said he has little hope that things will ever change, grew even gloomier when he discussed his grown children:

They've never seen the better side of life, they work meaningless low paying jobs and have terrible health care...I do think our best years are behind us. But they were never [as] great as we thought.

Similarly, Carol compared her own experiences first entering the workforce with those of her current coworkers in the healthcare industry. "I graduated in the 1970s right when the median wage started to flatten," said Carol. Nevertheless, she believed in the American Dream, and managed to get through college and into a job with relative ease. Yet today she sees that those same lab techs and other professionals that once would have been middle class now can't afford their retirement or mortgage.

Both left and right populists blame politicians, particularly those from their own party, for these losses. Left populists mention the Clinton administration as a flashpoint for when things started to go wrong with the Democrats. In retrospect, Carol blames Clinton-era policies like the removal of the Glass-Steagall Act of $1932^{5}$ and the North American Trade Agreement (NAFTA). ${ }^{6}$ Reflecting on her slow realization about what these policy changes meant, she said, "Who did this work out for? Corporations and rich people." Walter, a Sanders supporter from a neighboring county, said he first became disillusioned with the Democrats under Jimmy Carter, when the party began to shift towards neoliberalism. Yet he also holds particular ire for the Clintons, whom he views as a unit. "It is hard to express the depth of my anger towards the loss of 
manufacturing," he said. "I can't think of how to describe the damage he [Bill Clinton] did to working Americans." Similarly, Tea Party members hold a lot of anger towards Republican officials, who they see as failing to live out conservative principles of small government and spending, due to corruption from the political establishment and big money.

While Occupy and Tea Party members align in their concerns about loss of economic stability as a result of party incompetence, their explanations of the causes diverge. Whereas Occupy members generally cite the pro-corporate shift in both parties, Tea Party members point to more individualized causes relating to changes in the culture. Brenda faulted young people for failing to value the sacrifices and hard work necessary to make a good living, and studying unrealistic subjects like "gender studies" in college. Then she reflected on the patriotism of her youth, when "we respected the process and flag and president," suggesting that for her, patriotism and prosperity go hand in hand.

While Tea Party members emphasize it more, members of both groups recall a strong sense of community in their neighborhoods-knowing neighbors, walking to school, and playing outside without fear. Occupy member Helen noted that when she grew up on the outskirts of Detroit in the 1930s, people walked most places, and her family had an ethic of "waste not, want not," saving everything from aluminum foil to rubber bands. Meanwhile Rose, an 86-year-old longtime environmental activist and Occupy member, seemed to combine the left and right explanations for loss of community, perhaps since she is a former Republican who switched parties in the Reagan era. She recalled how her father's company, Dow Chemical, a major employer in Midland, Michigan, sponsored a city orchestra. "Do corporations still do that now?" she asked. "Herbert Dow cared about his employees and his town. Corporations now aren't beholden to the country they grew initially in." For Rose, the modern distant attitude of corporations has had a profound negative effect on culture as a whole. "If you work for a boss that treats you with respect and furnishes your society, you have a whole different attitude on life," she mused.

Finally, members of both groups appear nostalgic for an era of comparatively less partisan rancor. Rose noted that her parents were Republicans, and that back then "they were a very moderate, decent, thoughtful party. I learned to care about the environment from my dad." Those on both the left and right lamented the loss of unbiased news media, typically referencing Walter Cronkite as an example of a trusted figure that no longer exists in the media.

While left populists do not idealize the 1950s to the same extent as right populists, they project many of the same values onto the era, including community, trust, and economic security. This nostalgic vision illuminates the democratic and social deficits that people feel in their current communities, such as social and political alienation, distrust in institutions, and economic insecurity. Thus the imagined "heartland" of the past allows populist supporters to envision a different kind of future for the nation.

\section{Populist Realizations and Alternative Media}

These narratives show that Occupy members link their current distrust to particular historical moments when parties or government failed to act in their interests. Yet, in many cases, they weren't concerned about these events in the historical moment. Instead, they describe particular moments of "realization," often coinciding with 
accessing alternative media sources or populist political communities. This route towards a populist view of politics corresponds with similar narratives among Tea Party members.

Left populists often trace their shift towards populist perspectives to the increasing frivolity, commercialism, and dishonesty of the news media, which they blame on corporate influence. Many say they do not watch any mainstream TV news and get the majority of their news from a set of alternative leftist media sources. Carol said she began to distrust the media during the constant coverage of President Clinton's affair with intern Monica Lewinsky in the 1990s, the moment when she stopped watching TV news:

It was weeks of nothing but Lewinsky... That was the beginning where it was obvious that it was infotainment, dramatization, sound bites, it wasn't really investigative reporting.

Reflecting on the recent outcry over "fake news" coming from the president and others, she said, "Well, it's been fake a long time. People will say it's the liberal media, I call it corporate media." As Charlie explained, "If all the TV and newspapers are owned by six corporations, you're not going to get honest news... It's the fox in the henhouse."

Rob and Sharon, a couple that attends Occupy together, pinpoint their distrust of both the media and government to discovering alternative left media in the1990s. "Stumbling on Free Speech TV on satellite dish... That just blew me away," said Rob. For the first time, he started hearing about how the U.S. had supported right-wing authoritarian regimes throughout Latin America under Reagan: "I was like, is this for real? It's been going on since Vietnam!" Others had more personal reasons for distrusting the US military, stemming from participation or protest in the Vietnam War. Charlie said he was politicized after participating in protests of the establishment Democrats and Vietnam War at the Democratic Convention of 1968, which ended in police repression. "I was struck dumb by the violence," said Charlie. "I had always figured if a cop does something, he would have a reason, but this was just-they were enjoying their work. I see that today in North Dakota ${ }^{7}$ and lots of other places."

Similarly, right populists distrust major news networks and stations and rely on a small set of right-wing sources. However, they mostly blame liberal bias in the education system and among individual journalists, rather than corporate influence. Mary, a Tea Party activist, traces her conversion from what she calls "unthinking liberalism" to populist conservatism to listening to Rush Limbaugh on the radio in the 1980s. Employing a common phrase among left and right populist supporters, she said, "it opened my eyes to how politics were."

\section{From Populist Outrage to Political Action}

As I have shown, both Occupy and Tea Party members perceive that political institutions and culture have changed over their lifetimes in ways that make it harder for most Americans to live a good life. As a result, they are angry and outraged at the elites they hold responsible. They feel especially betrayed by trusted politicians from their own parties who failed to acknowledge or address the problems that people face, including cultural losses to local and national communities, as well as economic and structural changes relating to economic globalization. These feelings motivate people to engage in politics with the intent of reforming institutions and political culture. 

City Occupy group, joined in 2016 hoping to meet others who were as angry as he was about the political and economic system. He believes that anger can be productive for making change in the face of overwhelming structural problems. "Every one of us [is] a part of an unjust system that exploits," he said. "I look around and think people need to be more angry [sic]. To posit means to put something on display, so talking about ugly things should be part of being positive." In other words, identifying injustice helps build a sense of what a just nation would look like. local politician in her early thirties, was motivated to volunteer for Bernie Sanders and then run for office herself out of deep frustration with the situations she saw people facing in her community.

not making it and it feels like no one cares. Corporations have swallowed up the politicians, they've taken over. It's angering, motivating. If you want to actually understand and live your values, talk to people.

She went on to describe the difficult living conditions she saw and heard about when she door knocked for various campaigns.

Sanders' supporters' sense of betrayal deepened during the 2016 election, when they perceived that the Democratic Party used its delegates and funds to back Clinton over Sanders. Paul, who served as a Sanders delegate at the Democratic National Convention, described his experience:

Bernie had four workshops scheduled... the DNC cancelled all four, they didn't want all these Bernie people excited ... Just one more thing that points the finger at the DNC, Hillary, Bill, all the insiders of the Democrats.

In part as a result of these experiences, Paul and other Occupy members became more active and vocal in the local county Democratic Party, where they lobbied for change to policies on superdelegates and campaign finance. Responding to the outcry, the DNC subsequently reduced the role of superdelegates in an attempt to bring the party together after the fractious 2016 primary elections. Tea Party members have been similarly vocal critics in the local county Republican Parties, where they have worked to push the party in a rightward and democratically transparent direction.

41 Finally, on a local level, both Occupy and Tea Party members were active participants in the years-long campaign to hold city officials and developers to account as the city underwent rapid economic expansion. Proposition 3, which passed in 2018 and is now in effect, mandates that City Council cannot grant permits for new buildings higher than 60 feet until they are approved by a vote of the people. The "Yes" campaign for Prop 3 echoed the populist narrative of national decline, with supporters lamenting that the new developments, raised rents, and influx of tourism resulted in losses for community cohesion, local character, and accessible services for the longtime residents of Traverse City.

Furthermore, the issue drew on distrust of local political institutions and corporations. Prop 3 supporters claimed that city officials had a history of approving taxpayer funds for private developments without sufficient transparency. On behalf of a local environmental nonprofit, Occupy member Helen issued the initial legal challenge to a development that kicked off the campaign, whereas several Tea Party members 
regularly voiced their discontent with the city permitting process at City Council meetings.

\section{The Left Populist People: Pluralism and Unity}

The preceding analysis of the left populist narrative helps illuminate how left populism's idea of the national people differs from versions on the right. On the one hand, Occupy members look back with nostalgia on an earlier era of U.S. politics when the working class had comparatively more power and polarization was lower. Yet they also acknowledge that some minorities had fewer rights in this era. Overall, they argue that groups of Americans face varying challenges but are also united through their mutually shared exploitation by elite institutions and corporate power in particular. This conception of the "people" is thus more pluralistic than right-wing varieties that often exclude portions of the working class on the basis of perceived work ethic, race, or religion. Yet it differs from more typical left-wing narratives in its focus on the "people," united through joint oppression from corporate elites and fueled by the righteous mass politics and protest.

Political theorist Ernesto Laclau's account of collective identity formation in populism helps make sense of this combination of difference and equivalency (2007). He contends that when people start to link together a variety of unmet demands, the group as a whole becomes bonded in antagonism to the unresponsive system, and to shared allegiance to a leader or symbolic idea that each demand can attach itself to. In the case of Occupy Wall Street, the unifying idea is the notion that the corporate interests or the $1 \%$ have made U.S. institutions less democratic, thus uniting the "99\%" in righteous indignation. This metaphor allows for a wide variety of interests to coalesce-including concerns about the environment, community losses, and media bias, among others.

This logic can be seen in the way Occupy members make sense of the varied oppressions that different Americans face. At the Saturday protests downtown, a large portion of Occupy signs deal with immediate and constantly shifting concerns facing specific populations, such as Native Americans, women, and African Americans. Many of these signs, reading "Black Lives Matter" or "Respect Women" were created in response to perceived threats from Trump as both candidate and President. They coexisted alongside more clear-cut populist signs that had long graced many Saturday protests, such as "The System Isn't Broken, It's Fixed," and "Billionaires bought our Democracy!" Steve, an Occupy member who works with a local indigenous rights organization, put it well when he articulated how the unique challenges of African Americans fit together with challenges that all Americans face:

It has become clearer and clearer that the increase in inequality is related to the financialization of American corporate structures, privatization of the prison system. We saw it from the inside, we lived most of our lives in African American communities...There's a portion of society that benefits from this. White people, yes, but also the $1 \%$ benefit way more.

When it comes to the balance between difference and equivalence, left populists clearly fall more to the difference end of the spectrum than right populists. Nevertheless, I found that the central framing of the economic oppression faced by the $99 \%$ or working people does allow for a vision of unity among the people. "Anything that's ever been accomplished for people is bottom up, not top down," said Helen, citing the importance 
of local community organizing over party-led politics. Dylan, the young socialist Occupier, put it more forcefully:

What counts as a political act are not the ones that involve polls and voting, it's standing up to police firing water cannons in winter in North Dakota... Pain is something that speaks, it's hard to fake."

This understanding of a "people" united by oppression is nevertheless tempered by the frustration members felt about the apparent apathy of fellow leftists who remained disengaged, ignoring their small protests week after week. Yet, they shared a rare moment of hope while reflecting on the first annual Women's March, inspired by Trump's electoral victory, which members attended in Traverse City as well as in the Michigan capital, Lansing.

Ellen: It was more emotional for me the second day, I had no idea so many were there in Lansing. Then on Sunday I was on Facebook for hours looking at the demonstrations all over the world.

Helen: I'm waiting on a report from my granddaughter [who attended the DC march with a college feminist group]. The young people will keep us going.

Beverly: It made the world feel like a planet, [and] we were all in it.

This uncharacteristically hopeful moment for the group expressed the yearning at the root of their ongoing political actions-for a feeling of solidarity with their fellow citizens. That ordinary people coming together to protest and scrutinize could begin to change the unjust systems controlling their lives.

\section{Conclusion}

While this study is based on the dynamics of particular groups of people in one U.S. city, the patterns found in these groups can help explain the rise of populism at this particular political moment across the globe. While the populist movements and administrations that have recently emerged vary broadly, they each express a search for political alternatives amid rapid social and economic change and increasing distrust of traditional institutions and organizations that have failed to mediate these changes. In our current moment, both left and right populist narratives provide a compelling story that helps explain and respond to rising polarization, community fragmentation, and the uneven economic effects of globalization. While the specific grievances will vary across context, and the mostly elderly participants in my study likely felt these changes more strongly than younger people would, these ongoing shifts affect people across the world.

The discourse and practices of the Traverse City Occupy Wall Street and Tea Party groups illustrate both similarities and differences between left and right versions of grassroots populism. Most strikingly, the two groups subscribe to similar narratives of decline based in nostalgia for a "heartland" from their youth in the 1940s-70s. Members describe a downward trajectory for the nation over the course of their lifetimes, and feel a strong sense of loss when they reflect on memories from an era when they felt more strongly connected to their communities, more economically secure, and more trusting of political institutions. They are outraged at the elites who let these losses occur, reserving particular ire for politicians in their own political parties. In turn this outrage led to political action, with members of both groups motivated to hold their respective political parties to account, protest and advocate for issues they care about, 
and join community boards or run for local political office. Thus grassroots populism on both left and right increases political participation and engagement.

51 On the other hand, differences between these narratives also illuminate broader differences between left and right populism. Occupy members hold a more inclusionary and pluralistic notion of the "people" as comprising everyone but the elite. Thus, their version of populism exhibits more flexibility in responding to demands from a variety of different communities, demonstrating the greater capacity of grassroots left populism to enact truly democratic alternatives to unresponsive political institutions.

Given these real differences between left and right populists, one might ask, why should scholars bother to widen conceptualizations of populism so that they are inclusive to movements and left-wing varieties? After all, we could simply categorize Occupy Wall Street as a progressive social movement. Perhaps, as many scholars argue, including the Occupy Wall Street movement and a leader like Donald Trump in the same category of politics results in conceptual stretching, and a loss of usefulness in the concept. Yet, while narrowing the definition of populism may result in increased parsimony, it is important to consider the effects that academic concepts have beyond academia. At a time of high journalistic and popular interest in understanding the rise of populist politics across the world, scholarship on populism inevitably contributes to setting the parameters for popular understandings and responses. Thus, if left-wing, inclusive, and grassroots varieties are left out of stories of populism, the average citizen might be left with the impression that democracy is threatened by populism. On the other hand, if left-wing politicians and grassroots movements are also presented as populist, this same citizen might start to wonder why so many people with distinct ideologies all appear to be outraged about democratic institutions. In this case, the implications might be exactly the opposite - that rising inequality around the globe is a real threat, and even a crisis for liberal democracy, and that the many faces of populism are a symptom of that crisis.

\section{BIBLIOGRAPHY}

Akkerman, Agnes, Zaslove, Andrej, and Cas Mudde, "How Populist are the People?

Measuring Populist Attitudes in Voters", Comparative Political Studies, vol. 47, $n^{\circ}$ 9, 2014, p. $1324-1353$.

BBC News, "Jair Bolsonaro: Brazil's firebrand leader dubbed the Trump of the Tropics”, BBC News, December 31 2018, https://www.bbc.com/news/world-latin-america-45746013, page consulted January 7, 2019.

Bloch, Matthew, Larry Buchanan, Josh Katz, and Kevin Quealy, “An Extremely Detailed Map of the 2016 Election”, The New York Times, July 25, 2018, https://www.nytimes.com/interactive/2018/ upshot/election-2016-voting-precinct-maps.html\#6.02/43.67/-84.56, page consulted August 5, 2018.

Canovan, Margaret, Populism, New York, NY, Harcourt Brace Jovanovich, 1981. 
Frank, Thomas, What's the Matter with Kansas? How Conservatives Won the Heart of America, New York, Henry Holt and Company, 2004.

Grattan, Laura, Populism's Power: Radical Grassroots Power in America, New York, Oxford University Press, 2016.

Hawkins, Kirk Andrew, "Is Chavez populist? Measuring populist discourse in comparative perspective", Comparative Political Studies, vol. 42, n 8, 2009, p. 1040-67.

Hofstadter, Richard, “The Paranoid Style in American Politics.” Harper's Magazine. November, 1964, https://harpers.org/archive/1964/11/the-paranoid-style-in-american-politics/ ${ }_{2}$ page consulted March, 2018.

Honig, Bonnie, Emergency Politics: Paradox, Law, Democracy, Princeton, Princeton University Press, 2009.

Kazin, Michael, The Populist Persuasion: An American History, Ithaca, Cornell University

Press, 1995.

Laclau, Ernesto, On Populist Reason, London, Verso, 2005.

Lopes, Marina, "Making Brazil great again: How Jair Bolsonaro mirrors and courts Trump", The Washington Post, December 31, 2018, https://www.washingtonpost.com/world/the_americas/ making-brazil-great-again-how-jair-bolsonaro-mirrors-and-courts-trump/2018/12/29/df8bf7faf1d9-11e8-99c2-cfca6fcf610c_story.html?utm_term=.22225cea75c4, page consulted January 7 , 2019.

Morone, James, The Democratic Wish, New Haven, Yale University Press, 1990.

Mudde, Cas, “The Populist Zeitgeist”, Government and Opposition, vol. 39, n 3, 2004, p. 541-563.

Mueller, Jan-Werner, What is Populism?, Philadelphia, University of Pennsylvania Press, 2016. Norris, Pippa and Ronald Inglehart, Cultural Backlash: Trump, Brexit, and Authoritarian Populism, Cambridge, Cambridge University Press, 2019.

Riofrancos, Thea, "Populism Without the People: On Chantal Mouffe," N+1 Magazine, November 23, 2018. https://nplusonemag.com/online-only/online-only/populism-without-the-people/, page consulted May 20, 2019.

Skocpol, Theda and Vanessa Williamson, The Tea Party and the Remaking of Republican Conservatism, Oxford, Oxford University Press, 2012.

Skocpol, Theda and Alexander Hertel-Fernandez, "The Koch Network and Republican

Party Extremism." American Political Science Association, vol. 14, n 3, 2016, p. 681-699. doi:10.1017/ S1537592716001122.

Taggart, Paul, Populism, Buckingham, Open University Press, 2000.

Urbinati, Nadia, "Populism and the Principle of Majority" in Cristóbal Rovira Kaltwasser, Paul Taggart, Paulina Ochoa Espejo, and Pierre Ostiguy (eds.), The Oxford Handbook of Populism, New York, Oxford University Press, 2017, p. 571-589. 


\section{NOTES}

1. Occupy Wall Street began as a months-long occupation near the Wall Street financial district in New York City that aimed to bring attention to economic inequality in the wake of the 2008 financial crisis.

2. Indivisible is a national organization with local chapters that was created as a progressive Tea Party by several congressional staffers just after the election of Donald Trump. Among other activities, members make coordinated phone calls relating to national and local politics.

3. While I share Kazin's (1995) contention that it is not useful to call someone a populist (particularly since almost no one calls themselves a populist), in an effort to make comparisons, I refer to supporters of politicians and groups that employ populist narratives and modes of practices as left or right populists.

4. While the $9 / 12$ movement is a distinct organization, I refer to the group as the Tea Party henceforth, since its members also attended Tea Party protests and identify more broadly with the Tea Party movement.

5. The Glass-Steagall Act was designed to separate commercial banking from investment banking and prevented commercial banks from engaging in a number of investment activities. Some argue that the repeal led indirectly to the 2008 financial crisis.

6. Both Trump and Sanders criticized NAFTA during the 2016 presidential campaign, arguing that it led to a loss of American manufacturing jobs.

7. Charlie is referring to the months-long occupation and protests by members of the Standing Rock Sioux tribe and other activists in order to block construction of an oil pipeline that threatened Native water supplies, a subject which the Occupy members discussed frequently, receiving updates from a fellow member who was at the occupation.

\section{ABSTRACTS}

The election of Donald Trump and the rise of anti-immigrant parties throughout Europe have led many to define populism as exclusionary and anti-democratic. Yet inclusive, grassroots, and leftwing varieties of populism have also surged across the world in the same period. This paper aims to conceptualize left populism through the discourse of its supporters. I draw on interviews and observations with supporters of Bernie Sanders and members of Occupy Wall Street in Northern Michigan, gathered before and after the 2016 presidential campaign. I find that left-wing populists feel that it has become harder for the average American to live a decent life due to growing corporate influence on institutions. Like right populists, they are outraged at the failures of elites to acknowledge people's lived realities. However, unlike right populists, they acknowledge that minority populations face unique challenges. Contrary to theorists who claim that populism is incompatible with pluralism, I show that the left populist narrative of oppression by the " $1 \%$ " allows for both difference and unity within the "people".

L'élection de Donald Trump et la montée de partis anti-immigration à travers l'Europe ont amené de nombreux observateurs à définir le populisme comme un mouvement anti-démocratique et d'exclusion. Pourtant, des variantes populistes inclusives, populaires et de gauche ont également pris leur essor durant la même période. Cet article cherche à conceptualiser le populisme de gauche à travers le discours de ses partisans. Je me base sur des entrevues auprès de 
sympathisants de Bernie Sanders et du mouvement Occupy Wall Street et d'observations réalisées au cours de rassemblements pendant et après la campagne présidentielle de 2016 dans le nord du Michigan. Je conclus que les populistes de gauche estiment que l'Américain moyen a aujourd'hui moins de chances de mener une vie décente en raison de l'influence croissante des entreprises sur les institutions. Comme les populistes de droite, ils s'indignent de l'inaptitude des élites à reconnaître la réalité vécue du peuple. Cependant, à l'inverse des populistes de droite, ils reconnaissent que les minorités font face à des défis uniques. Contrairement aux théoriciens qui soutiennent que le populisme et le pluralisme sont incompatibles, je montre que le récit populiste de gauche de l'oppression par le « $1 \%$ » permet à la fois la différence et l'unité au sein $\mathrm{du}$ « peuple.»

La elección de Donald Trump y el aumento de los partidos antiinmigración en Europa ha hecho que muchos definen el populismo como excluyente y antidemocrático. Sin embargo, las variedades de populismo inclusivas, de base, y de izquierda han aumentado también a través de todo el mundo en el mismo período. Este artículo pretende conceptualizar el populismo de izquierda usando el discurso de sus partidarios. Saco mis conclusiones de entrevistas y observaciones con partidarios de Bernie Sanders y miembros de Occupy Wall Street en el norte de Michigan, obtenidas durante y después de la campaña presidencial de 2016. Concluyo que los populistas de izquierda y derecha sienten que las posibilidades de vivir una vida digna han disminuido debido a la creciente influencia corporativa en las instituciones. Al igual que los populistas de derecha, están indignados por la incapacidad de las élites para reconocer la realidad vivida por el pueblo. Sin embargo, a diferencia de los populistas de la derecha, reconocen que las poblaciones minoritarias enfrentan desafíos únicos. Contrariamente a los teóricos que afirman que el populismo es incompatible con el pluralismo, muestro que la narrativa populista de izquierda de la opresión por el "1\%" permite tanto la diferencia como la unidad dentro del "pueblo".

\section{INDEX}

Mots-clés: populisme, pluralisme, mouvements sociaux, ethnographie, Occupy Wall Street

Keywords: populism, pluralism, social movements, nationalism, Occupy Wall Street

Palabras claves: populismo, pluralismo, movimientos sociales, etnografía, Occupy Wall Street

\section{AUTHOR}

\section{RACHEL MEADE}

I am a fifth year Ph.D. candidate in Comparative and American politics. My dissertation investigates the processes by which citizens connect with populist political parties, groups, and leaders, and form their conceptions of "us" and "them". My primary methods are participant observation and interviews with members of local political groups in the U.S. and Argentina, as well as surveys and survey experiments to reveal how people process political news and populist discourse. Other research interests include political identity, emotion in politics, nationalism, and party-society linkages. Rachel_meade@brown.edu 